\title{
RELATIONSHIP BETWEEN HIGHER-ORDER THINKING AND ENGLISH ACHIEVEMENT
}

\author{
Ernis Sholihah, Suprihadi, Nuraeningsih \\ Universitas Muria Kudus
}

\begin{abstract}
Higher-order thinking skills (HOTS) is a new concept of thinking in Curriculum 2013 in Indonesia, which is based on the revised top three levels in Bloom's Taxonomy: analyzing, evaluating, and creating. This survey research used 44 students who were purposively sampled. The objective of this research was to determine if there was a linear correlation between HOTS and the English achievement of the eleventh grade students of SMA N 2 Kudus. Using Pearson's Product Moment Correlation in the level of significance .05 and degree of freedom 42, this research showed that there was a high positive significant linear correlation between HOTS and the English achievement of the eleventh grade students of SMA N 2 Kudus.
\end{abstract}

Key words: hots, taxonomy, curriculum 2013, english achievement

\section{INRODUCTION}

Educational system in Indonesia has changed the curriculum from the Institutional Based Curriculum (KTSP) to the newest curriculum, that is, Curriculum 2013 (K-13), which focuses on balancing among cognitive, affective, and psychomotor aspects. Based on Permendiknas no 70 (2014) the purpose is to prepare Indonesian students to be individuals who are devout, productive, creative, and innovative in this globalization era. Until today, K-13 has been revisedseveral times: in 2016, 2018, and the newest revision happened in 2020.

This curriculum change causes the development in every aspect of teaching and learning process, such as in arranging syllabus and lesson plan, developing the material, media, approach and also method of learning. The application of Curriculum 2013 requires that the mindset and the thinking ability of teachers and students should change from lower-order thinking skills (LOTS) to higher-order thinking skills (HOTS). HOTS has become the new concept in education reform which is used in Indonesia recently based on the top three levels of Bloom's taxonomy of cognitive domain, which include analyzing, evaluating, and creating (Kaur\&Ghanapati, 2014). It is the ability and expertise to find answer or achieve targeted goals through various forms of thinking processes (Budsankom, 2015).

HOTS focuses more on the students' elaboration in learning by combining critical and creative thinking of the students rather than only finishing the task given by the teacher. In this way, students will have the responsibility to manage their learning using their own way creatively, and the teacher as the facilitator will provide the media and give the guidance. According to Nadia (2015), HOTS is given and emphasized in the curriculum to produce critical and creative students, so that they can compete with others in international level. It is similar with Alsowat's statement (2016) that there is a clear evidence of students' engagement 
derived from student-centered learning and that it increases students' achievement in the learning process.

In English teaching and learning activities, HOTS focuses on the students' engagement in the lesson and spur their interest at the same time with the use of learning style and any kinds of media, while the teacher facilitated them by ensuring that they will be able to decide their own way to learn. As Teemant (2016) found that when the teacher intentionally engaged students in higher-order thinking, the students learn more. That is what Indonesian schools are trying to do and reaching recently, both of state as well as private schools, and SMA N 2 Kudus is one of the schools that have applied HOTS. Based on the data of the students' English score that the researchers got from the teacher, there were some students who got low scores and could not reach the minimum standard criteria (KKM). It means that the objective of English subject had not been reached yet by the students.

The low achievement might be due to the internal factor coming from the students, for example, the level of intelligence and the level of motivation and the external factors such as the school facilities, the family condition, and also the education system itself. In addition, in the application of HOTS there is a problem related to the students' engagement. Students have different level of engagement even when the teacher has provided HOTS in the process of teaching and learning. There are some students who still have low engagement in the learning process and they do not want to think more critically and creatively. They only did what the teacher said and completed the assignment without having a creative way to reach a better result and only did as a mere formality. This situation caused different achievement among the students. In line with that, it caused the situation which divided the students into two groups: the students with HOTS and the students with LOTS. This is similar with Hasnor (2013) who found that the students' academic achievement was directly proportional with the low-high usage in applying the approach and strategy in learning itself. However, Khan (2016) found out that by using HOTS the students' engagement was improved and they were more interested in learning activity. Therefore, it automatically influenced their English achievement. It is in line with Alsowat's (2016) investigation that there was a high significant relationship between the students' engagement in HOTS and their achievement in the learning process, so that it will be effective to increase the students' activeness, critical thinking, and creative thinking.

As it has been stated before, the curriculum which is now implemented in most secondary schools in Indonesia is Curriculum 2013. One of the differences of the new curriculum with the previous one is in the concept in developing the students' way of thinking. While the former curriculum focuses on lower-order thinking skills (LOTS) which only develops the students' receptive skills, Curriculum 2013 focuses on the development of high-order thinking skills (HOTS) that is related to critical thinking and creative thinking (Margana, 2013). It covers the three highest parts of Bloom's taxonomy: analyzing, evaluating, and creating. Figure 1 illustrates the development of the original Bloom's Taxonomy in the form of pyramid. 


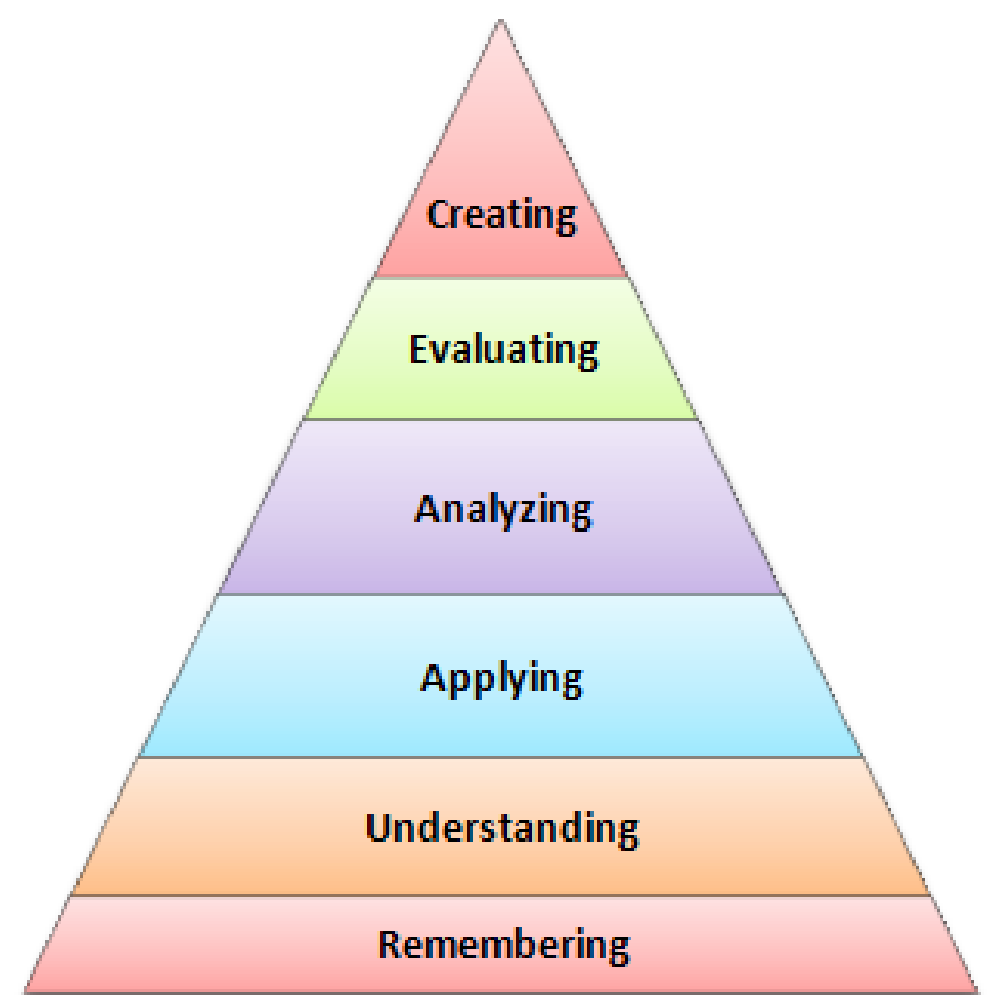

Figure 1. Bloom's Taxonomy of Cognitive Domain

HOTS in Curriculum 2013 requires the students to employ greater responsibility for their own learning, because the scientific approach nowadays changed the teacher-centered learning to student-centered learning. It will arouse curiosity, encourage critical thinking, and stimulate creativity of the students based on their own way of learning. The term of learning approach refers to the students' intentions when facing a learning situation and the way they do their assignments (Hasnor,2013), Therefore, it is predicted that HOTS will be very influential in the process of teaching and learning activity.

According to Kaur and Ghanapati (2014), HOTS engages students in active learning, experiences their autonomy in learning, researching, and developing their personal skills related to their critical and creative thinking based on the integration of HOTS on Bloom's taxonomy which is described in the form of Frangenheim's Thinking Skills Framework. 


\begin{tabular}{|c|c|c|c|}
\hline Bloom Level & $\overline{\text { Verbs }}$ & Starters & \\
\hline Creating & $\begin{array}{l}\text { Design } \\
\text { Extrapolate } \\
\text { Improve } \\
\text { Invent } \\
\text { Predict } \\
\text { Propose } \\
\end{array}$ & $\begin{array}{l}\text { Design a database for... } \\
\text { Formulate criteria to judge... } \\
\text { Develop argument... } \\
\text { Design an action plan... } \\
\text { Create a role play... } \\
\text { Design brochure... }\end{array}$ & \\
\hline Evaluating & $\begin{array}{l}\text { Argue } \\
\text { Assess } \\
\text { Conclude } \\
\text { Critique } \\
\text { Decide } \\
\text { Judge } \\
\end{array}$ & $\begin{array}{l}\text { To what extent... } \\
\text { Justify the decision of... } \\
\text { Select option... } \\
\text { Evaluate the effectiveness... } \\
\text { Validate the accuracy... } \\
\text { Determine which is effective... }\end{array}$ & $\mathbf{T}$ \\
\hline Analyzing & $\begin{array}{l}\text { Debate } \\
\text { Deconstruct } \\
\text { Differentiate } \\
\text { Discuss } \\
\text { Distinguish }\end{array}$ & $\begin{array}{l}\text { Compare... } \\
\text { Analyze from perspective... } \\
\text { Summarize view points... } \\
\text { Conduct research on... } \\
\text { List the pros and cons... }\end{array}$ & $\mathbf{S}$ \\
\hline Applying & $\begin{array}{l}\text { Calculate } \\
\text { Compile } \\
\text { Complete } \\
\text { Demonstrate } \\
\end{array}$ & $\begin{array}{l}\text { Apply previous knowledge... } \\
\text { Complete a site map for... } \\
\text { Demonstrate how to... } \\
\text { Construct a flow chart... } \\
\end{array}$ & \\
\hline Understanding & $\begin{array}{l}\text { Classify } \\
\text { Comprehend } \\
\text { Discuss } \\
\text { Explain } \\
\text { Interpret }\end{array}$ & $\begin{array}{l}\text { Explain how... } \\
\text { Give reason for... } \\
\text { Research to understand... } \\
\text { State } 3 \text { things you know... } \\
\text { Describe early... }\end{array}$ & 0 \\
\hline Remembering & $\begin{array}{l}\text { Define } \\
\text { Find } \\
\text { Label } \\
\text { Memorize } \\
\text { Recall }\end{array}$ & $\begin{array}{l}\text { Name all the... } \\
\text { Describe what happened... } \\
\text { Search the internet for... } \\
\text { What is... } \\
\text { List... }\end{array}$ & $\mathbf{S}$ \\
\hline
\end{tabular}

Figure 1.Frangenheim's (2006) Thinking Skills Framework

Frangenheim's model (2006) encourages $21^{\text {st }}$ century skills of critical and creative thinking to be acquired through questioning at the appropriate level by incorporating a range of collaborative and co-operative learning. It means that in teaching and learning activity, HOTS depends on how the teacher facilitates and leads the students' engagement during the process of learning. So, the outcomes will be achieved through a combination of the content knowledge that is delivered by the teacher and how the students involve in learning process.

HOTS provides a guidance that will facilitate students during the learning process with the teacher as the facilitator. It will also influence the students through various activities that require them to be more attractive and more active. HOTS makes the students experience projects and group-based works both independently and collaboratively as their responsibility to reach their own achievement.

English as an international language becomes one of the compulsory subjects at schools in Indonesia, because mastering English is one of the requirements to take part in international level. That is why the education is really 
important for the country, and then the government takes more interest in developing a better education system to produce people with high qualification. It is one of causes why our curriculum changed.

As has been stated before, Curriculum 2013 is the curriculum that is used by the schools in implementing the education. It provides HOTS as the new concept of thinking to guide the teacher as facilitator in teaching and learning activity to take students' interest especially in learning process at school and at home. This approach does not only influence the students' engagement at school but also at home or outside the class when they learn (Du, Fu \& Wang, 2014). It is because they are required to think more critically and creatively in doing the tasks that they get from the school or in preparing the next material for discussion or presentation with their friends for the next lesson.

The implementation of HOTS in teaching and learning activity cannot be separated from the use of LOTS that had become the basic skills since the students were at elementary schools and focuses on receptive skills by giving knowledge through the teacher's explanation. However, in applying HOTS teachers will involve the students by using more various media such as videos, audios, reading materials, pictures etc., and also the types of tasks written or spoken that will provide challenging learning which are interesting for the students. They have to learn by using the media and try to understand the material based on their own way of thinking, critically and creatively. In this way, they will be more active because the dominant involvement comes from themselves with the guidance from the teacher as the facilitator who helps them in learning the material and doing the task.

HOTS also focuses more on students' practice which is drilled through dialogues, presentation, and group discussions. It requires students to have collaborative works with others during the learning process and it might motivate the students to help each other with their friends if they have difficulties in their learning. It will improve their English related to the cognitive aspect which includes listening, reading, speaking, and writing.

In applying HOTS during the learning process, the students' affective and psychomotor aspects will be improved too since they have to learn together and collaborate with each other which is in line with their independence to choose their own ways of learning using HOTS. The role of the teacher as facilitator here will provide them some options or alternative ways that they can use by considering what they need to reach the goals of learning. It is similar with Rusiana's statement (2016) that the more the teacher provides persistent practices and activities, the more the students will be able to think critically and to develop their higher order thinking skill. In this way, the students' autonomy in learning process which influences their responsibility about their own study and their awareness to manage their learning time both at school and at home to get the targeted goals.

HOTS represent more sophisticated and context-rich thinking processes that include critical, logical, reflective, and meta-cognitive also creative thinking (Nadia, 2014). In this sense, HOTS enables students to elevate their level of 
thinking by connecting their knowledge with the cognitive domain: analyzing, evaluating and creating.

In applying HOTS, teachers play the role of facilitators who provide the media that will be used to deliver the material, design the model or strategy in teaching and learning process through the lesson plan, and also choose what kind of activity that will draw the students' interest. That is the main concept of HOTS which purposes to make students more active, critical and creative. So, it will increase students' engagement and motivation as well as their achievement especially in English subject.

When the students get involved in every activity, they should be more critical in thinking about what they have learned and what they have to learn. They will develop their own way of learning based on their consideration. It is similar with Alsowat (2016) who states that students' engagement involves high level of participants and a high quality of effort in learning process. HOTS requires them to be critical and creative thinkers both individually and in groupwork.

In English learning, HOTS influences all language skills: listening, speaking, reading, and writing. Teachers as facilitators here provide various activities which are designed by using HOTS that will make students get involved in the learning activities. The students will enjoy engaging in the activities and they will get a better understanding through the questioning and discussing sessions. Therefore, it is predicted that the application of HOTS in teaching and learning activities has a correlation with the students' English achievement.

\section{METHOD}

This correlational research was conducted to find out the linear relationship between HOTS and the English achievement of the eleventh grade students of SMA N 2 Kudus. The variables involved were HOTS score as variable $\mathrm{X}$ and English achievement score as $\mathrm{Y}$ variable.

The subjects of the research were 44 students out of 381 from 11 classes. From each class, the top four who applied HOTS based on the questionnaire scores, were purposely selected.

To collect the data, questionnaire and documentation were used. The questionnaire was used to identify the students' engagement in relation with the implementation of HOTS in teaching and learning activities. The questionnaire was an adaptation of the one used by Khan (2016). It was a close-ended questionnaire consisting of 20 items, which comprise 16 items about HOTS and 4 items about LOTS. Documentation was used to get the data of the students' English achievement in the final exam.

The technique used to analyze the data was Pearson Product Moment Correlation.To find out whether or not there is a significant correlation between HOTS and the English achievement, the researchers used the null hypothesis that there is no significant correlation $\left(\mathbf{H}_{\mathbf{0}}: \boldsymbol{r}_{\boldsymbol{x}}=\mathbf{0}\right)$. The criteria to reject or accept the null hypothesis are as follow:

1. Reject $\mathrm{H}_{0}$ and accept $\mathrm{H}_{\mathrm{a}}$ if $r_{x y} \geq r_{t}$. 
2. Accept $\mathrm{H}_{0}$ and reject $\mathrm{H}_{\mathrm{a}}$ if $r_{x y} \leq r_{t}$.

\section{FINDINGS AND DISCUSSION}

The results of analyzing the questionnaire to identify the students who applied HOTS and the English achievement were presented in Table 1:

Table 1

HOTS Scores and English Achievement Scores of the Eleventh Grade Students of SMA N 2 Kudus

\begin{tabular}{ccc}
\hline & \multicolumn{2}{c}{ Scores } \\
\cline { 2 - 3 } No. & HOTS & $\begin{array}{c}\text { English } \\
\text { Achievement }\end{array}$ \\
\hline 1 & 56 & 74 \\
\hline 2 & 53 & 72 \\
\hline 3 & 72 & 78 \\
\hline 4 & 53 & 76 \\
\hline 5 & 64 & 82 \\
\hline 6 & 55 & 74 \\
\hline 7 & 42 & 72 \\
\hline 8 & 66 & 76 \\
\hline 9 & 65 & 74 \\
\hline 10 & 69 & 78 \\
\hline 11 & 73 & 88 \\
\hline 12 & 67 & 82 \\
\hline 13 & 74 & 92 \\
\hline 14 & 81 & 86 \\
\hline 15 & 73 & 80 \\
\hline 16 & 75 & 84 \\
\hline 17 & 80 & 82 \\
\hline 18 & 74 & 78 \\
\hline 19 & 73 & 80 \\
\hline 20 & 73 & 84 \\
\hline 21 & 67 & 78 \\
\hline 22 & 59 & 78 \\
\hline & & \\
\hline
\end{tabular}

\begin{tabular}{ccc}
\hline & \multicolumn{2}{c}{ Scores } \\
\cline { 2 - 3 } No. & HOTS & $\begin{array}{c}\text { English } \\
\text { Achievement }\end{array}$ \\
\hline 23 & 79 & 82 \\
\hline 24 & 69 & 74 \\
\hline 25 & 66 & 82 \\
\hline 26 & 63 & 72 \\
\hline 27 & 67 & 80 \\
\hline 28 & 68 & 78 \\
\hline 29 & 54 & 70 \\
\hline 30 & 62 & 80 \\
\hline 31 & 58 & 74 \\
\hline 32 & 60 & 82 \\
\hline 33 & 78 & 80 \\
\hline 34 & 75 & 86 \\
\hline 35 & 74 & 90 \\
\hline 36 & 71 & 84 \\
\hline 37 & 71 & 86 \\
\hline 38 & 93 & 88 \\
\hline 39 & 66 & 78 \\
\hline 40 & 66 & 80 \\
\hline 41 & 63 & 74 \\
\hline 42 & 64 & 76 \\
\hline 43 & 75 & 78 \\
\hline 44 & 62 & 80 \\
\hline & & \\
\hline
\end{tabular}

From the data in Table 1 we can see that the highest HOTS score is 81 , the lowest score is 42 , and from the calculation the mean is 67.45 , which shows highlevel engagement. Meanwhile, the highest English score is 92, the lowest score is 70 and the mean is 79.59 .

Based on the calculation using Pearson-product moment correlation formula it was found that $\mathrm{r}_{\mathrm{xy}}$ was 0.697 . In the level of significance (one-tailed) .05 and degree of freedom 42 (44 - 2), the $r_{\text {table }}$ is 0.251 . It means that $r_{x y}(0.697)$ is 
bigger than $r_{\text {table }}(0.251)$ so that the null hypothesis was rejected and the research hypothesis was accepted. In other words, there was a positive significant correlation between the application of HOTS and the English achievement of the eleventh grade students of SMA N 2 Kudus.

The fact that there was a significant positive correlation between the application of HOTS and the English achievement indicated that the higher the score of HOTS the higher the English achievement would be. With relatively strong correlation coefficient $\left(r_{x y}=0.697\right)$ it was very possible that there was also causal relationship between those two variables. Some reasons why HOTS had significant correlation and possibly influenced the students' English achievement because HOTS focused on student-centered learning and gave authority to the students who were responsible for their own learning related to their engagement in English learning activity. This is similar with Alsowat's statement (2016) that high level of students' engagement and high effort in learning process was influential toward students' achievement. When the engagement is high and they involve intensively on the learning process, their English achievement will be high too. On the contrary, when they have low engagement, the English achievement will be low too.

\section{CONCLUSION AND SUGGESTION}

After conducting the research and analyzing the data, it could be concluded that in the level of significance .05 and degree of freedom 42, there was a significant strong positive linear correlation between HOTS and English achievement of the students of SMA 2 Kudus. The correlation coefficient of $r_{x y}$ was 0.697 and the $r_{\text {table }}$ was 0.251 .

After knowing the result of the research, we suggest that teachers should be able to conduct HOTS in teaching and learning activities by facilitating the students through the use of teaching media, teaching strategies, and teaching material which will increase the students' engagement in HOTS. In addition, the result of this research can be used as one of the references related to the investigation of the causal relationship between the application of HOTS and English achievement.

\section{REFERENCES}

Alsowat, Hamad. (2016). An EFL Flipped Classroom Teaching Model: Effects on English Language Higher-Order Thinking Skills, Student Engagement and Satisfaction. Journal of Education and Practice, 9(7), 108-121. Retrieved from: www.iiste.org.

Budsankom, Prayoonsri. (2015). Factors Affecting Higher Order Thinking Skills of Students: A Meta- analytic Structural Equation Modelling Study.Academic Journals, 10(9), 2639-2652.Retrieved from: http://www.academicjournals. org/ERR. 
KementrianPendidikanNasional.(2014).PermendiknasNomor $70 \quad$ Tahun 2014.KerangkaDasardanStrukturKurikulumSekolahMenengahKejuruan/ Madrasah AliyahKejuruan.

Du, S., Fu, Z. Wang, Y. (2014).The FlippedClassroom- Advantages and Challenges.International Conference on Economic Management and Trade Cooperation, 17-20. doi: 10.2991/emtc-14.2014.3.

Frangenheim, E. 2006.Thinking Skills Framework.[online] Retrieved: 15 January, 2014. Available at: http://www.itcpublications.com.

Hasnor, HaninNaziha., Ahmad,Zaiton, \&Nordin,Norshidah. (2013). The Relationship between Learning Approach and Academic Achievement Among Intec Students, Uitm Shah Alam. Procedia: Social and Behavioral Sciences, 90, 178-186. Retrieved from: www.sciencedirect.com.

Kaur, Sajit\&Ganapathy, Malini.(2014). ESL Students' Perception of the Use of Higher Order Thinking Skills in English Language Writing. Australian International Academic Centre, 5(5), 80-87. Retrieved from: http://dx.doi.org/10.7575/aiac.alls.v.5n.5p.80.

Khan, IrshadShaista.(2016). Critical Thinking in a Higher Education Functional English Course.Europan Journal of Educational Research, 9(7), 59-67. Retrieved from: www.iiste.org.

Margana.(2013). Empowering Students' Creativity in Making sense of English texts with the Use of Higher Order Thinking Skills.Proceeding JETA Conference. Yogyakarta: Sahara Press.

Nadia, Siti. (2015). Teachers' Perception on the Integration of HOTS in Language Teaching.International Journal of Technical Resaerch and Application, 22, 42-44. Retrieved from: www.ijtra.com.

Rusiana. (2016). Higher-Order Questions to Promote Critical Thinking.Proceeding: Teaching, Linguistic, Culture and Education, Conference, 156-163. Kudus: BadanPenerbitUniversitasMuria Kudus.

Teemant, Annela. (2016). The Effects of Higher Order Thinking on Student Achievement and English Proficiency.ITJ, 13(1). 